ICAMS 2016 $-6^{\text {th }}$ International Conference on Advanced Materials and Systems

\title{
ESSENTIAL OIL COMPONENTS OF FRESH CORIANDER (CORIANDRUM SATIVUM L.) HERBS FROM DIFFERENT LOCATIONS IN TURKEY
}

\author{
MUSA TURKMEN, NADIRE PELIN BAHADIRLI, AHMET MERT \\ Mustafa Kemal University, Faculty of Agriculture, Department of Field Crops, Medical Plants \\ 31030, Antakya-Hatay, Turkey
}

\begin{abstract}
Five different Coriander (Coriandrum sativum L.) obtained from different sources were cultivated under Hatay ecological conditions used as a plant material. To determine essential oil rate fresh herbs of coriander were analysed with Neo-Clevenger apparatus by the method steam distillation. Essential oil components were determined by gas chromatography-mass spectrometry (GC-MS) apparatus. Decanal (9.95-16.53), 2-Decanal (3.48-11.86), 1-Decanol (7.67-17.13), Cyclodecanol (4.46-13.78), 2-Dodecenal (5.42-12.65), Cyclododecanal (5.23-7.86) and 13-Tetradecanal (4.87$11.19)$ were found main components.
\end{abstract}

Keywords: Coriandrum, GC-MS, Essential oil

\section{INTRODUCTION}

Coriandrum sativum L. (Coriander) is a annual, medicinal plant from the Umbelliferae/Apiaceae family. Coriander known as "aşotu", "kişniş" or "kizbara" in Turkish language. It has long known and used for food preservation (Potter, 1996; Gil et al., 2002), flavouring agent and alternative medicine. Despite coriander naturally grown in the Mediterranean region plant widely produced in India, Morocco, Bangladesh, Canada, USA and Mexico, in India and Bangladesh mostly consume in local markets (Small, 1997). World total annual production of coriander (including anise, badian and fennel) leaves and seeds in 2013 was 940.587 ton (FAO stat, 2013). Coriander exports of Turkey in 2013 were 229 tons for USD 566.088.

Coriander become more and more economically important because of biological active compounds by powdered seeds, dry extract, tea, tincture and decoction. The main biological compound is EO which posses antimicrobial (Delaquis et al., 2002), antibacterial (Bown, 1995), antioxidant (Rajeshwari et al., 2012), antidiabetic (Aissaoui et al., 2011) activities.

Coriander essential oil yields and componenet wide range by age, origin, environmetal factors and ontogenesis (Carrubba and Torre, 2002; Msaada et al., 2007; Kiralan et al., 2009; Kosar et al., 2005; Yildirim and Gok, 2012; Baser and Kirimer, 2014).

The main component of essential oil is vary from the different parts of plant. In seed main component is linalool while in flowers Benzofuran,2,3- dihydro and in leaves Decanal, Dodecanal found as main component (Msaada et al., 2007; Mandal and Mandal, 2015).

In this study, 5 coriander (Coriandrum sativum L.) seeds, from different sources, cultivated in Hatay conditions, fresh herb were obtained for essential oil components. 


\section{MATERIALS AND METHODS}

\section{Plant Material}

Coriander seeds from 5 different sources of Turkey (1.Denizli, 2.Hatay/Altınözü, 3.Ankara, 4.Burdur, 5.Hatay/Samandağ) were cultivated during season 2015-2016, Mustafa Kemal University field area in Hatay.

\section{Essential Oil Isolation}

Air-dried plant samples $(200 \mathrm{~g})$ were placed in a 11 round-bottom distillation flask and $300 \mathrm{ml}$ distilled water added. The essential oils were obtained by steam distillation for $3 \mathrm{~h}$ with Clevenger's apparatus, according to European Pharmacopoeia method (Council of Europe, 1997). The oils were separated, dried over anhydrous sodium sulphate and stored in an amber bottle at $4{ }^{\circ} \mathrm{C}$ until used.

\section{GC-MS Analysis of Essential Oil}

Analysis of the essential oils used in these experiments was performed using a Hewlett-Packard 6890 gas chromatography (GC) linked to a Hewlett-Packard 5973 mass selective detector equipped with a HP-5 MS (Crosslinked $5 \%$ Phenyl Methyl Siloxane) capillary column ( $30 \mathrm{~m} 0.25 \mathrm{~mm}$ i.d., $0.25 \mathrm{~mm}$ film thickness). The carrier gas was helium, at a rate of $1.3 \mathrm{ml} / \mathrm{min}$. The oven temperature was initially $45^{\circ} \mathrm{C}$, then increased at $2{ }^{\circ} \mathrm{C} / \mathrm{min}$ to $130 \mathrm{C}, 3 \mathrm{C} / \mathrm{min}$ to $170{ }^{\circ} \mathrm{C}$, then to $10{ }^{\circ} \mathrm{C} / \mathrm{min}$ to $220{ }^{\circ} \mathrm{C}$ and finally isothermal for $5 \mathrm{~min}$. The ionization energy was $70 \mathrm{eV}$. The interface temperature was $250{ }^{\circ} \mathrm{C}$. The essential oil components were tentatively identified by comparing their relative retention times and mass spectra with those of Wiley Registry of Mass Spectral Data (McLafferty, 1994) and publication of Adams (Adams, 1995).

\section{RESULTS AND DISCUSSION}

Chemical composition of essential oil of Corianders showed smilar profiles and differed quantitatively (Table 1).

In our study main components of essential oils of sample 1 (seeds supplied from Denizli location) were found Decenal $11.26 \%$, 2-Decenal $11.86 \%$, 2-Dodecenal 12.65 $\%$. In sample 2 (seeds supplied from Altinozu/Hatay-202 m), main components were found Decenal $10.81 \%$, 2-Decenal $10.02 \%$, 1-Decanol $10.39 \%$, Cyclodecanol 10.24 $\%$ and 2-Dodecenal $10.56 \%$. Essential oil components of Sample (seeds supplied from Ankara) 3 were found as, Decenal 16.53\%, 1-Decanol 13.21 \%, 2-Dodecenal $10.40 \%$, 13-Tetradecenal $11.19 \%$. Essential oil components of Sample 4 (seeds supplied from Burdur) were found 1-Decanol $16.16 \%, 13$-Tetradecenal $10.11 \%$ and Decenal $9.95 \%$. In Sample 5 (seeds supplied from Samandag/Hatay- $15 \mathrm{~m}$ ) essential oil composition vary as Decenal $11.84 \%$, 2-Decenal $10.30 \%$, 1-Decanol $13.16 \%$ and Cyclodecanol $13.78 \%$. The results show that even in the same city but different altitutes can effect on essential oil components and components quantity. Potter and Fagerson (1990) were studied coriander fresh leaves from Massachusetts to obtain essential oil composition. In the study, 2-decenal $46.1 \%$, 2-undodecenal $10.3 \%$, 2-undecenal $5.6 \%$ and decenal $4.4 \%$ were found as main components. Freires et al. (2014) were investigated coriander 
ICAMS $2016-6^{\text {th }}$ International Conference on Advanced Materials and Systems

essential oil cultivated in Brazil (University of Campinas). In the study decenal (19.09 $\%)$, trans-2-decenal (17.54 \%), 2-decen-1ol (12.33\%) and cyclodecane (12.15\%) found as major componenets of coriander fresh leaves essential oil. Matasyoh et al. (2008) study coriandrum fresh leaves from Kenya. The researchers reported that coriandrum essential oils main components are 2E-decenal (15.9\%), decanal (14.3\%), 2E-decen-1ol $(14.2 \%)$ and $n$-decanol (13.6\%). Although our results vary according to the study conducted by Potter and Fagerson (1990), it was similar to the results of the studies conducted by Freires et al. (2014), Matasyoh et al. (2008).

Table 1. Essential oil composition (\%) of coriander fresh herb

\begin{tabular}{llllllll}
\hline RT & Cas \# & Compound Name & 1-Denizli & 2-Altınozu & \multicolumn{3}{l}{ 3-Ankara 4-Burdur } \\
\hline 17.1 & $112-31-2$ & Decanal & 11.26 & 10.81 & 16.53 & 9.95 & 11.94 \\
21.02 & $112-44-7$ & Undecanal & 3.37 & 3.73 & 3.70 & 2.80 & 3.77 \\
22.41 & $3913-81-3$ & 2-Decenal, (E)- & 11.86 & 10.02 & 3.48 & 4.61 & 10.30 \\
24.89 & $112-54-9$ & Dodecanal & 4.50 & 4.11 & 7.55 & 5.67 & 4.56 \\
26.31 & $2463-77-6$ & 2-Undecenal & 5.46 & 4.74 & 1.67 & 1.77 & 3.41 \\
26.88 & $112-30-1$ & 1-Decanol & 8.29 & 10.39 & 13.21 & 16.16 & 13.16 \\
28.64 & $10486-19-8$ & Tridecanal & - & - & 1.53 & - & - \\
28.81 & $1502-05-2$ & Cyclodecanol & 8.71 & 10.24 & 4.46 & 8.64 & 13.78 \\
30.1 & $4826-62-4$ & 2-Dodecenal & 12.65 & 10.56 & 10.40 & 6.46 & 7.03 \\
30.43 & $112-42-5$ & 1-Undecanol & 1.90 & 2.70 & 1.61 & 2.56 & 2.80 \\
32.29 & $31502-14-4$ & 2-Nonen-1-ol, (E)- & 4.11 & 4.70 & - & 3.31 & 4.14 \\
32.27 & $124-25-4$ & Tetradecanal & - & - & 2.94 & - & - \\
32.52 & $504-96-1$ & Neophytadiene & - & - & 1.00 & 1.20 & - \\
33.86 & $112-53-8$ & 1-Dodecanol & - & 1.07 & 1.19 & 1.90 & 1.17 \\
35.67 & $1724-39-6$ & Cyclododecanol & 7.26 & 7.86 & 5.14 & 5.73 & 5.35 \\
37.2 & $85896-31-7$ & 13-Tetradecenal & 6.64 & 6.12 & 11.19 & 10.11 & 4.87 \\
40.52 & $2423-10-1$ & Olealdehyde & 1.38 & 1.45 & 3.63 & 2.77 & 1.05 \\
42.02 & $69064-37-5$ & trans-2-Dodecen-1-ol1.69 & 2.20 & 2.81 & 5.39 & 2.06 \\
52.57 & $150-86-7$ & Phytol & 1.12 & - & 1.98 & 3.34 & 1.04 \\
\hline
\end{tabular}

\section{CONCLUSION}

The results reported of variation on coriander fresh herb essential oil seed supplied from five different sources of Turkey and cultivated in same ecological conditions. This study illustrates the impact of the genotype on components of volatile oil. In our study Decanal (9.95-16.53 \%), 2-Decanal (3.48-11.86 \%), 1-Decanol (7.67-17.13 \%), Cyclodecanol (4.46-13.78 \%), 2-Dodecenal (5.42-12.65\%), Cyclododecanal (5.23-7.86 $\%)$ and 13 -Tetradecanal (4.87-11.19\%) were found as main componenets.

\section{REFERENCES}

Adams, R.P. (1995), Identification of Essential Oil Components by Gas Chromatography/Mass Spectroscopy, Carol Stream, IL: Allured Publishing.

Aissaoui, A., Zizi, S., Israili, Z.H. and Lyoussi, B. (2011), "Hypoglycemic and hypolipidemic effects of Coriandrum sativum L. in Meriones shawi rats", Journal of Ethnopharmacology, 137(1), 652-661.

Baser, K.H.C. and Kirimer, N. (2014), "Essential oils of Anatolian Apiaceae - A profile", Natural Volatiles and Essential Oils, 1(1), 150.

Bown, D. (1995), The Royal Horticultural Society Encyclopedia of Herbs and Their Uses, Dorling Kindersley Ltd. London, p. 424. 


\section{Essential Oil Components of Fresh Coriander (Coriandrum sativum L.) Herbs from Different Locations in Turkey}

Carrubba, A., Torre, R., Di Prima, A. et al. (2002), "Statistical analyses on the essential oil of Italian coriander (Coriandrum sativum L.) fruits of different ages and origins", Journal of Essential Oil Research, 14, 389396.

Council of Europe (1997), European Pharmacopoeia, 3rd edn. Strausbourg, 121-122.

Delaquis, P.J., Stanich, K., Girard, B. and Mazza, G. (2002), "Antimicrobial activity of individual and mixed fractions of dill, cilantro, coriander and eucalyptus essential oils", International Journal of Food Microbiology, 74(1-2), 101-109.

FAO stat (2013), http://faostat.fao.org/site/291/default.aspx.

Freires, I.A., Murata, R.M., Furletti, V.F. et al. (2014), "Coriandrum sativum L. (Coriander) Essential Oil: Antifungal Activity and Mode of Action on Candida spp., and Molecular Targets Affected in Human Whole-Genome Expression", PLoS ONE, 9(6): e99086. doi:10.1371/journal.pone.0099086.

Kiralan, M. (2006), Ayçiçek Yağının Oksidadtif Stabilitesi Üzerine Isırgan (Urtica diocia L.), Keten (Linum usitassium L.), Kişniş (Coriandrum sativum L.) ve Çörekotu (Nigella sativa L.) Tohum Ekstraktlarının Etkileri. Ankara Üniversitesi, Fen Bilimleri Enstitüsü, Gıda Mühendisliği Anabilim Dalı, Yüksek Lisans Tezi (Danışman: Prof. Dr. Ali Bayrak), Ankara.

Kosar, M., Ozek, T., Goger, F., Kurkcuoglu, M. and Baser, K.H.C. (2005), "Comparison of microwaveassisted hydrodistillation and hydrodistillation methods for the analysis of volatile secondary metabolites", Pharmaceutical Biology, 43(6), 491-495.

Mandal, S. and Mandal, M. (2015), "Coriander (Coriandrum sativum L.) essential oil: chemistry and biological activity", Asian Pacific Journal of Tropical Biomedicine, 5(6), 421-428.

Matasyoh, J.C., Maiyo, Z.C., Ngure, R.M. and Chepkorir, R. (2009), "Chemical composition and antimicrobial activity of the essential oil of Coriandrum sativum", Food Chemistry, 113, 526-529.

McLafferty, F.W. (1994), Wiley Registry of Mass Spectral Data, New York.

Msaada, K., Hosni, K., Taarit, B.M., Chahed, T., Kchouk, E.M. and Marzouk, B. (2007), "Changes on essential oil composition of Coriander (Coriandrum sativum L.) fruits during three stage of maturity", Food Chemistry, 102, 1131-1134.

Potter, T.L. and Fagerson, I.S. (1990), "Composition of Coriander Leaf Volatiles", Journal of Agricultural and Food Chemistry, 38: 2054-2056

Potter, T.L. (1996), "Essential oil composition of cilantro", Journal of Agricultural and Food Chemistry, 44, 1824-1826.

Rajeshwari, C.U., Siri, S. and Andallu, B. (2012), "Antioxidant and antiarthritic potential of coriander (Coriandrum sativum L.) leaves", e-SPEN Journal, 7(6), e223-e228.

Small, E. (1997), Culinary herbs, Ottawa, NRC Research Press, pp 219-25.

Yildirim, B. and Gok, N. (2012), "Effect of Sowing Date and Varieties on Essential Oil Ratio and Essential Oil Components of Coriander (Coriandrum sativum L.) in Van Ecological Condition", Journal of Animal and Veterinary Advances, 11(11), 1925-1929. 